\title{
Changes in Carbohydrate and Nitrogen Relationships during Episodic Growth of Ligustrum japonicum Thunb.
}

\author{
Jeff S. Kuehny \\ Louisiana State University Agricultural Center, Department of Horticulture, 137 Julian C. Miller Hall, \\ Baton Rouge, LA 70803-2120; \\ William B. Miller ${ }^{2}$ and Dennis R. Decoteau \\ Clemson University, Department of Horticulture, Box 340375, Clemson, SC 29634-0375
}

AdDitional INDEX words. autoradiograph, ${ }^{14} \mathrm{C}$ labeling, glucose, mannitol, ${ }^{15} \mathrm{~N}$, protein, shoot growth, root growth

\begin{abstract}
Rooted cuttings of Ligustrum japonicum Thunb., an episodically growing species, were grown hydroponically in a controlled-environment growth chamber to determine allocation of glucose, mannitol, total soluble sugars, and total protein in mature leaves, flush leaves, stems, and roots. During the 65 days of episodic growth, $43 \%$ of the total soluble sugars was glucose and $33 \%$ mannitol. Glucose concentrations of mature leaves decreased during the first root growth episode, increased in almost all plant tissue during a shoot growth episode and decreased in all plant tissue at initiation of a second root growth episode. Mannitol concentrations in the roots and stems decreased during episodes of root growth and increased during a shoot growth episode when leaf flush mannitol concentrations increased. Radiolabeled $\mathrm{C}$ applied to leaves before the initiation of the first period of shoot elongation was translocated to the roots. After shoot elongation, just before a root growth episode, most labeled $C$ was translocated to new shoots and roots. Autoradiographs indicated that subsequent episodes of shoot growth were supported by photosynthate from the previous shoot flush. Protein concentrations decreased in all plant tissues during shoot growth but increased in roots and mature leaves during root growth. Concentrations of ${ }^{15} \mathrm{~N}$ in leaf and stem tissue indicated retranslocated $N$ supported each episode of shoot growth. Changes in endogenous $\mathrm{C}$ and $\mathrm{N}$ concentrations and allocation patterns in ligustrum were linked to the control of episodic shoot and root growth.
\end{abstract}

Alternate episodes of shoot and root growth are characteristic of many woody species (Bochert, 1991; Drew and Ledig, 1980; Kuehny and Halbrooks, 1993; Reich et al., 1980) and are defined as episodic. Previous studies suggests that an endogenous mechanism is involved in controlling episodic shoot and root growth. For example, researchers have correlated this type of episodic growth with changes in water (Bochert, 1991) or hormonal status (AboHamed et al., 1985). Bochert (1991) stated that the most puzzling aspect of episodic growth in trees is the cessation of shoot growth under environmental conditions that permit continued growth of herbaceous plants and seedlings of many tree species. Studies of Japanese holly (Ilex crenata Thunb.) (Mertens and Wright, 1978; Niemiera and Wright, 1982), euonymus (Euonymus japonica Thunb.) (Hershey, 1981), and cocoa (Theobroma cacao L.) (Bird and Hardwick, 1982; Sleigh et al., 1984) suggest that allocation of carbohydrates and $\mathrm{N}$ contribute to episodes of shoot and root growth.

Partial defoliation during a period of shoot growth in cocoa resulted in an increase in size of the remaining leaves during that episode that was proportional to the fraction of leaves removed (Bird and Hardwick, 1982). Leaves of that episode of shoot growth compete for a limited $\mathrm{C}$ resource from older leaves, and they postulated that the length of the shoot growth episode was determined by the carbohydrate supply. Roots of cocoa grew more rapidly if new leaves were removed during a shoot growth episode;

Received for publication 24 June 1996. Accepted for publication 2 May 1997. Approved for publication by the director of the Louisiana Agricultural Experiment Station as manuscript no. 96-28-0194. We thank Mary A. Topa for critical review of the manuscript. We are grateful to Paul V. Nelson, Nancy C. Mingis, Richard Volk, and Penelope Windsor for the use of their labs and technical assistance. This research was conducted by J.S. Kuehny in partial fulfillment of the requirements for a $\mathrm{PhD}$ at Clemson Univ. The cost of publishing this paper was defrayed in part by the payment of page charges. Under postal regulations, this paper therefore must be hereby marked advertisement solely to indicate this fact. however, if roots were removed there was a delay in the next episode of shoot growth (Sleigh et al., 1984). Carbohydrate concentrations in mature cocoa tissue and ${ }^{14} \mathrm{C}$ allocation data indicated that reduced root growth during shoot growth was correlated with reduction in transport of photoassimilates to roots and an increased allocation to the new episode of shoot growth (Sleigh et al., 1984).

Nitrogen may also influence episodic growth. The time required for each episode of shoot growth of Japanese holly to reach $2 \% \mathrm{~N}$ and the interval between episodes varied with level of $\mathrm{N}$ applied (Gilliam and Wright, 1978b). Japanese holly grown at 300 $\mathrm{ppm} \mathrm{N}$ reached $2 \% \mathrm{~N}$, at which time a new episode of shoot growth was initiated 9 and 13 weeks before plants grown at 150 and 50 ppm N, respectively. Fertilizer applications made between episodes of shoot growth resulted in a higher percentage of $\mathrm{N}$ in recently mature leaf tissue and greater shoot growth than applications made during other stages of growth (Gilliam and Wright, 1978a). Nitrate uptake decreased in euonymus during an episode of shoot growth and increased when the episode of shoot growth ceased (Hershey and Paul, 1983).

Raper et al. (1978) proposed a conceptual model of interdependence of shoot and root growth in Nicotiana tabacum L. (a nonepisodic plant), in which a continuous cycle of carbohydrates from shoots to roots and $\mathrm{N}$ from roots to shoots maintains $\mathrm{C}$ fixation by shoots and nitrate uptake by roots. Raper's model can be extended to episodic plants, in that episodic plants achieve a functional balance of growth by using a noncontinuous supply of carbohydrate and N. Carbon dioxide is fixed by photosynthetically active leaves and carbohydrate stored in the leaves and stems and then transported to the roots. Nitrogen is absorbed by the roots, assimilated, stored, and then transported to stems and leaves. Distribution of $\mathrm{C}$ and $\mathrm{N}$ in storage pools may be involved in the regulation of episodic shoot and root growth.

One such C pool could be mannitol, a sugar alcohol. Sugar alcohols are direct products of photosynthesis and can be translo- 
cated within the plant, and they also may serve as storage compounds (Loescher, 1987). Mannitol is the most frequently occurring sugar alcohol in plants and is thought to be a major translocation and storage sugar in Ascolano Olea trees (Priestly, 1977). Since ligustrum is also a member of the Oleaceae family and mannitol was found to be a major carbohydrate in Ligustrum vulgare L. (Loescher et al,, 1992), mannitol may have a role in episodic growth of Ligustrum japonicum Thunb.

Correlations between $\mathrm{N}$ and episodic growth reported by Gilliam and Wright (1978a, 1978b) and Hershey and Paul (1983) indicate that $\mathrm{N}$ storage pools may have a strong influence on episodic growth. Proteins are known to be potential N storage in woody plant species (Shim et al., 1983; Wetzel and Greenwood, 1989). Most studies on nutrient redistribution in plants, however, have investigated changes in total $\mathrm{N}$ content rather than protein content or composition (Staswick, 1989). Thus, protein concentration may be a good indicator of change in organic $\mathrm{N}$ concentration during episodic growth. Nitrogen assimilation, distribution, and storage has also been effectively determined by using the isotope ${ }^{15} \mathrm{~N}$ (Awonaike et al. 1991). Therefore, investigating the changes of protein concentrations and ${ }^{15} \mathrm{~N}$ concentration will be pertinent to understanding $\mathrm{N}$ storage and reallocation during episodic growth.

Four methods were used to examine changes in carbohydrate and $\mathrm{N}$ distribution in the roots, stems, and leaves of ligustrum during alternating episodes of shoot and root growth. They were as follows: determination of starch and soluble carbohydrate concentrations including mannitol, determination of protein concentration, ${ }^{14} \mathrm{C}$ pulse labeling with autoradiographs, and ${ }^{15} \mathrm{~N}$ pulse labeling with determination of ${ }^{15} \mathrm{~N}$ and $\mathrm{N}$ concentration. The objective was to determine if changes in distribution of carbohydrate and $\mathrm{N}$ in ligustrum, an episodic species, significantly change with episodes of shoot and root growth and therefore are significant endogenous factors controlling episodes of shoot and root growth.

\section{Materials and Methods}

Growing Conditions. Before each experiment, terminal cuttings of Ligustrum japonicum Thunb. with four mature leaves per cutting were stuck in flats containing sterilized sand and placed under intermittent mist. When the roots of cuttings were $\approx 8 \mathrm{~cm}$ long, the sand was washed from the roots with distilled deionzed water. Experiments were conducted in a controlledenvironment growth chamber with $24 / 18^{\circ} \mathrm{C}$ day/night temperatures. Photoperiod was a 14$h$ day with an irradiance of $250 \mu \mathrm{mol} \cdot \mathrm{m}^{-2} \cdot \mathrm{s}^{-1}$. Fifty-two uniform rooted cuttings were grown hydroponically in containers, each container holding $2 \mathrm{~L}$ of aerated nutrient solution with one plant per container. The solution contained these macronutrients $(\mathrm{mM})-3.75 \mathrm{NO}^{3-}-\mathrm{N}, 0.25$ $\mathrm{PO}_{4}{ }^{3-}-\mathrm{P}, 1.5 \mathrm{~K}^{+}, 1.25 \mathrm{Ca}^{2+}, 0.5 \mathrm{Mg}^{2+}$, and 0.5 $\mathrm{SO}_{4}{ }^{2-}-\mathrm{S}$ - and micronutrients $(\mu \mathrm{M})-72 \mathrm{Fe}^{3+}, 93$ $\mathrm{B}^{3+}, 18 \mathrm{Mn}^{2+}, 1.5 \mathrm{Zn}^{2+}, 1.6 \mathrm{Cu}^{2+}$, and $0.1 \mathrm{Mo}^{2+}$. Sources of these nutrients were $\mathrm{KNO}_{3}$, $\mathrm{Ca}\left(\mathrm{NO}_{3}\right)^{2} \cdot 4 \mathrm{H}_{2} \mathrm{O}, \mathrm{KH}_{2} \mathrm{PO}_{4}, \mathrm{MgSO}_{4} \cdot 7 \mathrm{H}_{2} \mathrm{O}, \mathrm{Fe}$ EDTA, $\mathrm{H}_{3} \mathrm{BO}_{3}, \mathrm{MnCl}_{2} \bullet 4 \mathrm{H}_{2} \mathrm{O}, \mathrm{ZnSO}_{4}, \mathrm{CuSO}_{4}$, and $\mathrm{Na}_{2} \mathrm{MoO}_{4} \cdot 2 \mathrm{H}_{2} \mathrm{O}$. Nutrient solutions were sampled and changed every $5 \mathrm{~d}$ and nitrate- $\mathrm{N}$ concentrations of the sampled solutions were never below $2 \mathrm{~mm}$. Four plants were harvested just before the onset of the photoperiod in a completely randomized pattern each $5 \mathrm{~d}$, and plant parts were separated and grouped into mature leaves, mature stems, flush leaves, flush stems, and roots. Harvested plant tissue was immediately frozen in liquid $\mathrm{N}$ and stored at $-70^{\circ} \mathrm{C}$.

Growth ANaLYSIs. Length of each new shoot was determined every other day by measuring the length from the stem axis to the tip of the apical meristem. All shoot lengths were added together to give cumulative shoot length per plant to determine the shoot flush periods. Shoot and root fresh mass were determined every 5 $\mathrm{d}$ using a nondestructive measurement technique (Kuehny and Halbrooks, 1993) based on Archimedes' principle of buoyancy. The plant was suspended from an arm on an electronic balance with the roots submerged in nutrient solution and the mass was recorded as shoot fresh mass. Root fresh mass was calculated by the difference between shoot fresh mass and whole-plant fresh mass. Relative growth rate (RGR) was calculated according to Hunt (1982).

Carbohydrate analysis. Harvested plant tissues were lyophilized, weighed, and ground to 20 mesh. Twenty-five milligrams of stem tissue and $50 \mathrm{mg}$ of leaf and root tissue were used for carbohydrate analysis. Soluble sugars were extracted with 12 methanol : 5 chloroform : 3 water (by volume) for $3 \mathrm{~h}$ as described by Miller and Langhans (1989). Sorbitol (1 mg) was used as an internal standard and water was added to partition out the chloroform. After centrifugation the aqueous phase was applied to a polyethylene column containing $1 \mathrm{~mL}$ polyvinylpolypyrolidone, 1 $\mathrm{mL}$ Dowex 50-W, and $1 \mathrm{~mL}$ Amberlite IRA-45 (Sigma Chemical Co., Saint Louis). Subsequent high-performance liquid chromatography (HPLC) of soluble sugars and starch analysis on tissue residue was as described earlier (Miller and Langhans, 1989).

Protein analysis. Protein concentration was assayed using a modification of the method of Jones et al. (1989). Four milliliters of $0.1 \mathrm{~N} \mathrm{NaOH}$ was added to $25 \mathrm{mg}$ of ground plant tissue. Samples

Fig. 1. Shoot relative growth rate $\left(\mathrm{RGR}_{s)}\right.$ and root relative growth rate $\left(\mathrm{RGR}_{\mathrm{r}}\right.$, over one shoot flush and initiation of a second in ligustrum cuttings. Horizontal bars indicate a cumulative increase in shoot elongation or flush period.

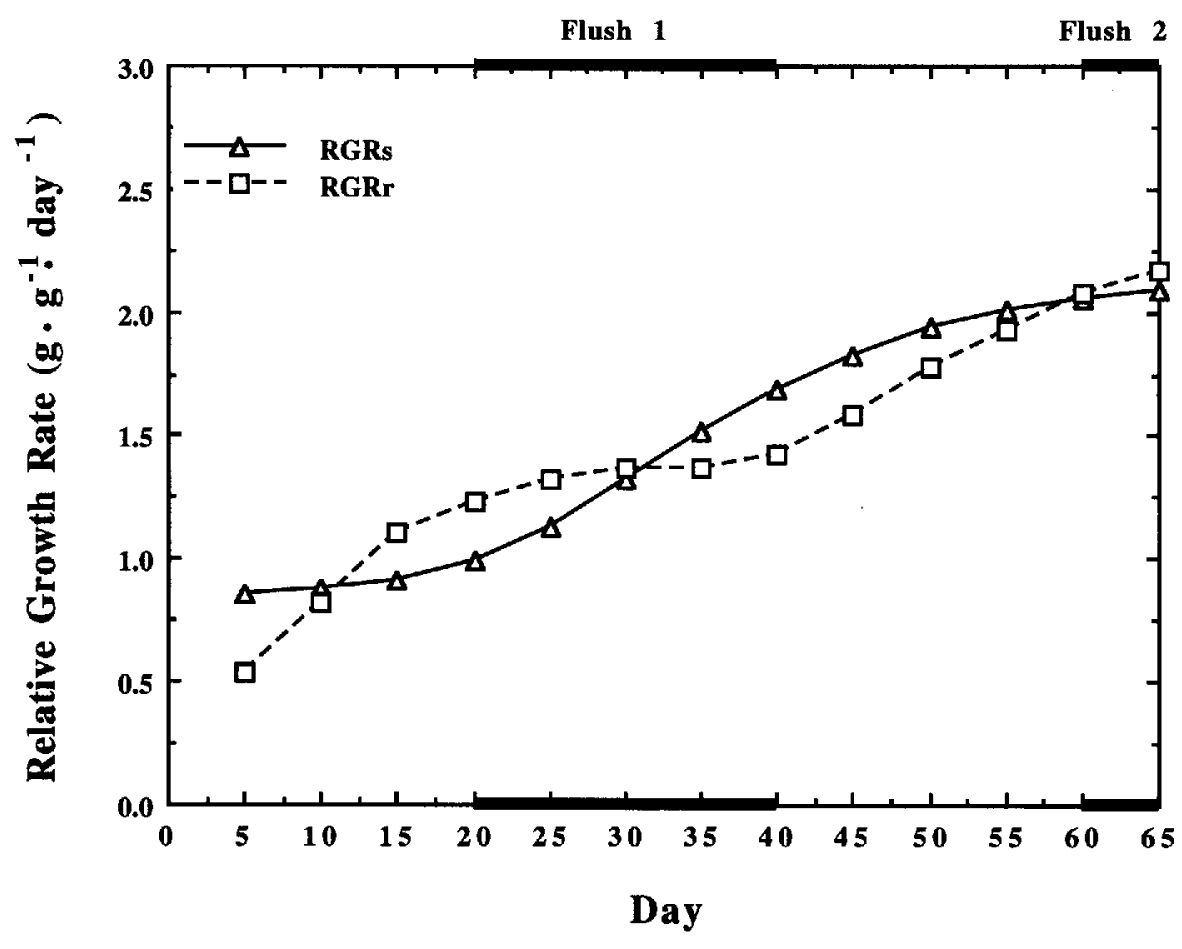


were agitated on a vortex mixer, extracted for $12 \mathrm{~h}$, mixed, and centrifuged for $10 \mathrm{~min}$ at $>5000 \mathrm{~g}_{\mathrm{n}}$. Aliquots $(100$ or $200 \mu \mathrm{L})$ were mixed with $5 \mathrm{~mL}$ of Bradford dye reagent (BioRad Laboratories, Richmond, Calif.) diluted 1:4 with water and absorbance at $595 \mathrm{~nm}$ was measured.

${ }^{14}$ CARBON PULSE LABEL. Nine terminal rooted cuttings of ligustrum having four mature leaves were grown under the same conditions as in the previous experiment. The plants were randomly divided into three groups of three plants for subsequent labeling and harvest at three different stages of growth: a) $5 \mathrm{~d}$ before initiation of the first period of shoot elongation (Harvest 1), b) at the end of first period of shoot elongation (Harvest 2), and c) at the initiation of the third period of shoot elongation (Harvest 3). For this experiment there were $20 \mathrm{~d}$ between the initiation and end of shoot elongation or a 20-d shoot flush.

The two lower leaves of the rooted cuttings were used for the first ${ }^{14} \mathrm{C}$ pulse label, the four mature leaves of the cutting were used for the second label, and two mature leaves of the first shoot flush were used for the third label. A 1-L plastic bag was placed over the specified leaves of each of three plants and sealed around the stem with florist tape. Sodium bicarbonate $\left(\mathrm{NaH}^{14} \mathrm{CO}_{3}\right)$ was injected into a container within the plastic bag and $185 \times 10^{4} \mathrm{~Bq}^{14} \mathrm{CO}_{2}$ was released after addition of lactic acid. For the second and third pulse, $92.5 \times 10^{4} \mathrm{~Bq}$ was released. After a 1 -h labeling period, the bags were removed and the plants were placed in the growth chamber for $22 \mathrm{~h}$ to allow translocation of labeled assimilate. Plants were then separated into shoot (mature stem and four leaves of original rooted cutting), root, and the two shoot flush portions. Each tissue was placed between two pieces of cardboard and then inserted in an envelope to keep the tissue pressed flat. The envelope was then immersed in liquid $\mathrm{N}$ and stored at $-70^{\circ} \mathrm{C}$ until lyophilized.

Samples were prepared for autoradiography using the method of Isebrands and Dickson (1991). Lyophilized plant material was arranged on a piece of $30-\mathrm{mm}$ cardboard that had been covered with heavy-duty aluminum foil and a sheet of white bond paper. Plastic wrap was pulled tight over the plant material to hold it in place and X-ray film (Cornex film, Du Pont, Wilmington, Del.) was placed on top of the plastic wrap for an exposure period of 1 week in darkness at room temperature.

${ }^{15}$ Nitrogen Pulse Label. Nine plants were exposed to nutrient solutions containing ${ }^{15} \mathrm{NO}_{3}^{-}$ ( 99 atom $\%{ }^{15} \mathrm{~N}$ ) for $5 \mathrm{~d}$ at the beginning of the experiment and then changed to the original solution. Plants were selected for three harvest dates as described for the ${ }^{14} \mathrm{C}$ experiment. At each harvest, plants were separated into roots, leaves and stems and frozen in liquid $\mathrm{N}$. Samples were stored at $-70^{\circ} \mathrm{C}$, lyophilized, and ground to 20 mesh. Total $\mathrm{N}$ concentration was determined on $200 \mathrm{mg}$ of each leaf tissue and $100 \mathrm{mg}$ of stem and root tissue by a microKjeldahl procedure (Eastin, 1978). The sample was distilled again and the distillate was collected in a disposable borosilicate glass test tube containing $0.5 \mathrm{~mL}$ of $0.1 \mathrm{~N} \mathrm{HCl}$. The atom percent ${ }^{15} \mathrm{~N}$ was determined mass spectrometrically using a freeze-layer procedure (Volk and Jackson, 1979).

STATISTICs. Means and standard errors were calculated for each day for the following variables: relative growth rate of shoots $\left(\mathrm{RGR}_{\mathrm{s}}\right)$, relative growth rate of roots $\left(R_{G} R_{r}\right)$, sugar concentration of each type of plant tissue, and protein concentrations of each type of plant tissue. These means were plotted against day. The plots were examined to determine if any possible pattern or trend across day existed. The method used to determine if a statistically significant trend existed was analysis of variance among days followed by pairwise $t$ tests. This method was used instead of regression analysis because no reasonable model could be fit to the patterns existing in the plots. All calculations were performed using the GLM procedure of SAS with the PDIFF option.

\section{Results}

GrowTH. The following growth results are for the plants used in the carbohydrate and protein portions of this study. The shoot flush period was defined as the interval of growth characterized by a cumulative increase in shoot elongation. Cumulative shoot elongation occurred for the first flush beginning on day 20 and ending on day 40 and a second flush of growth was initiated beginning on day 60 (Fig. 1). Based on a previous study, shoot and root growth episodes could be determined by a simultaneous evaluation of $R_{G R}, R_{s}$, and shoot elongation (Kuehny and Halbrooks, 1993). Changes in $\mathrm{RGR}_{\mathrm{s}}$ and $\mathrm{RGR}_{\mathrm{r}}$ in the present study varied over time and suggested the same pattern of alternate episodes of shoot and root growth observed previously (Fig. 1). Before the first shoot flush, RGR $_{\mathrm{r}}$ increased indicating a root growth episode (day 5 to 25). During shoot elongation (Flush 1), $\mathrm{RGR}_{\mathrm{s}}$ began to increase after day 20 , while $\mathrm{RGR}_{\mathrm{r}}$ was stable indicating the end of a root growth episode and initiation of a shoot growth episode. Inversely, after cessation of shoot elongation (end of Flush 1) on day 50, $\mathrm{RGR}_{\mathrm{s}}$ became constant indicating the end of

Fig. 2. Glucose concentration (mg. $\mathrm{g}^{-1}$ dry mass) in mature leaf $(\square)$, mature stem $(\Delta)$, root $(\mathbf{O})$, leaf flush $(\square)$, and stem flush ( $\boldsymbol{\Delta}$ ) tissue during episodic growth. Leaf flush and stem flush are the leaf and stem tissue from the first episode of shoot growth. Horizontal bars indicate a cumulative increase in shoot elongation or flush period. Each value represents the mean of four plants and vertical bars represent $\mathrm{SE}$.

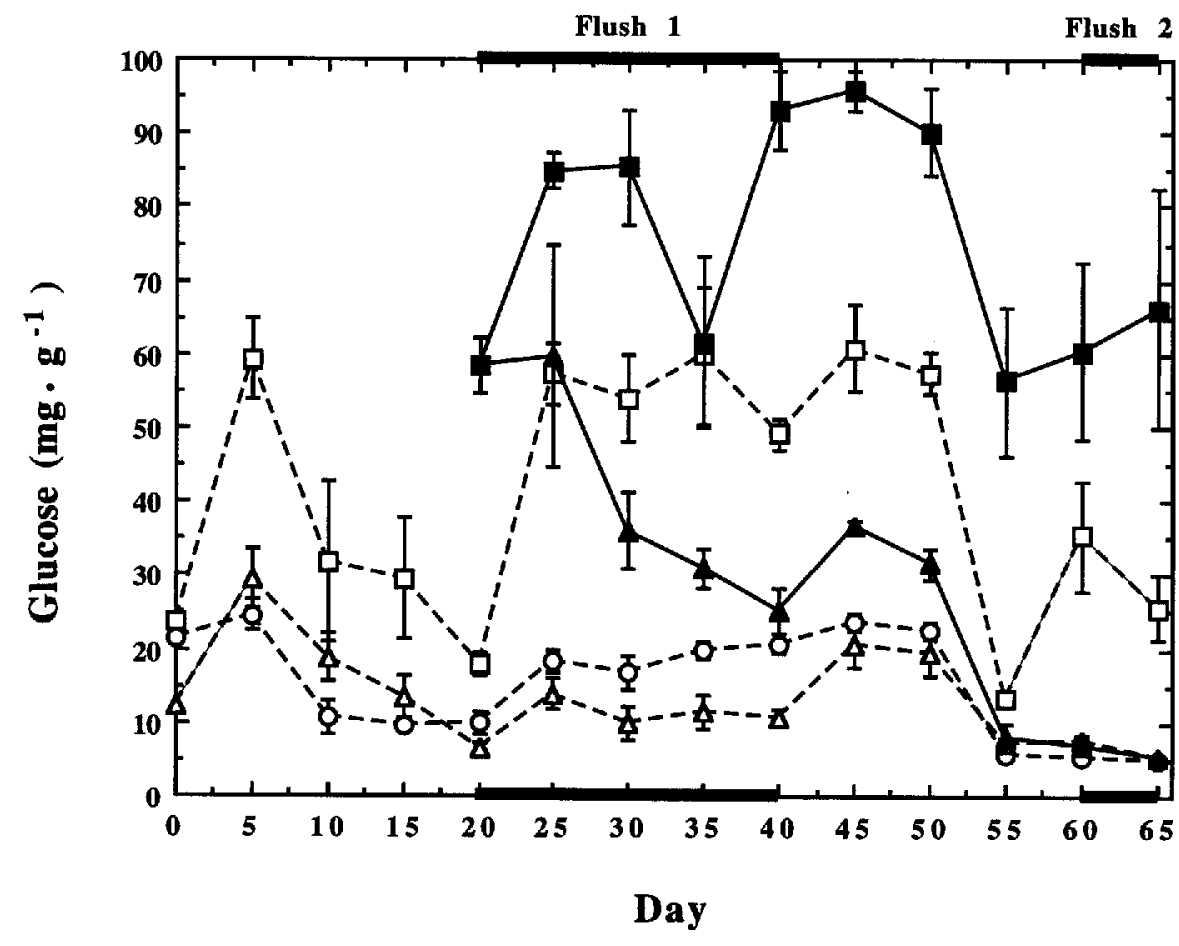


Flush 1

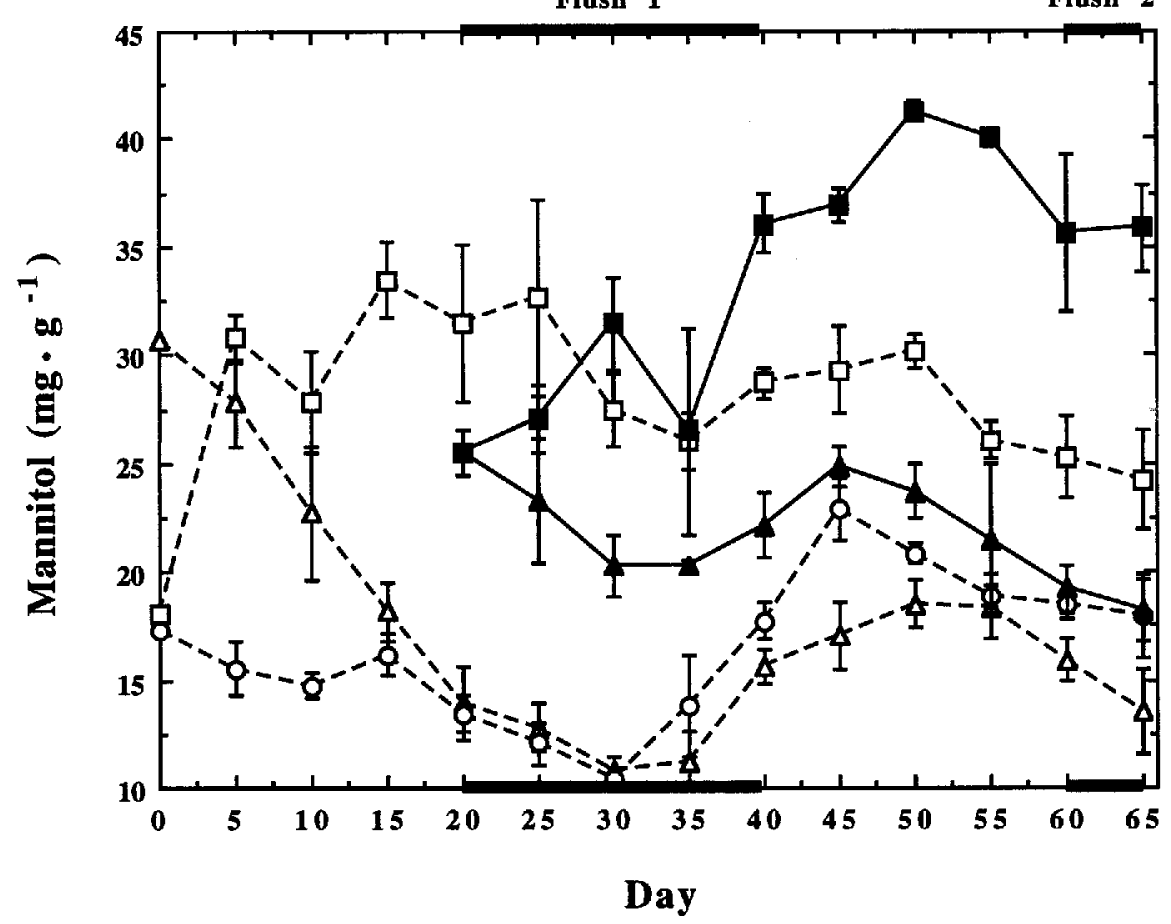

In mature stems and roots however, mannitol concentrations decreased during a root growth episode (Fig. 3). Concentration in the stems and roots increased after day 35 and 45 , respectively, during a shoot growth episode and before a root growth episode. Concentration of mannitol in the flush leaves generally increased during the shoot growth episode. Although mannitol concentration was higher in new stem growth than in the root and mature stem, the patterns of increase and decrease were similar.

Total soluble sugar concentration changed in a similar pattern as glucose and mannitol in all plant tissue, and starch concentrations were low in all tissue and indicated no significant patterns (data not shown).

ProteIn. Protein concentration in the mature leaves and roots increased during a root growth episode and remained high to day 20 (Fig. 4). Mature leaf and root protein concentration decreased after day 20 and remained low during and after (until day 50) shoot elongation. During a root growth episode, before initiation of the second shoot flush, protein concentration increased in all plant tissue.

Fig. 3. Mannitol concentration ( $\mathrm{mg} \cdot \mathrm{g}^{-1}$ dry mass) in mature leaf (D), mature stem $(\Delta)$, root $(\mathrm{O})$, leaf flush $(\square)$, and stem flush $(\boldsymbol{\Delta})$ tissue during episodic growth. Leaf flush and stem flush are the leaf and stem tissue from the first episode of shoot growth. Horizontal bars indicate a cumulative increase in shoot elongation or flush period. Each value represents the mean of four plants and vertical bars represent $\mathrm{SE}$.

the shoot growth episode, while $\mathrm{RGR}_{\mathrm{r}}$ began to increase (after day 40) before initiation of the second period of shoot elongation (Flush 2). Therefore, in this study there was one full root and shoot growth episode and the beginning of a second root growth episode. The first shoot flush (cumulative increase in shoot elongation) was part of the shoot growth episode (increased $\mathrm{RGR}_{\mathrm{s}}$ ), but shoot elongation ceased before the shoot growth episode had ceased. A second shoot flush (Flush 2) was initiated but a second shoot growth episode was not yet indicated by an increase in $\mathrm{RGR}_{\mathrm{s}}$.

Carbohydrates. Glucose accounted for the greatest amount of total soluble sugars (sum of sucrose, glucose, fructose, and mannitol) at an average $43 \%$ for the $65-\mathrm{d}$ growth period and mannitol was second highest at $33 \%$. Glucose concentration in mature leaves decreased between days 5 and 20 , before initiation of an episode of shoot growth, which coincided with a root growth episode (Fig. 2). Between day 20 and 45 , glucose concentration increased in all plant tissue except in the newly growing stem tissue. Glucose concentration in flushing tissue decreased during expansion. Glucose concentration decreased in all plant tissue after day 50 , when the first shoot growth episode ceased and the second root growth episode was initiated.

Contrary to glucose, mannitol concentration did not decrease and remained high in mature leaves during root growth (days 5-20).
Protein concentration in new leaf tissue was highest at the beginning of the first and second flush and decreased during the remainder of the flush; protein concentrations in stem flush tissue followed a similar pattern.

Fig. 4. Protein concentration ( $\mathrm{mg} \cdot \mathrm{g}^{-1}$ dry mass) in mature leaf $(\square)$, mature stem $(\Delta)$, root $(O)$, leaf flush $(\square)$, and stem flush $(\Delta)$ tissue during episodic growth. Leaf flush and stem flush are the leaf and stem tissue from the first episode of shoot growth. Horizontal bars indicate a cumulative increase in shoot elongation or flush period. Each value represents the mean of four plants and vertical bars represent SE.

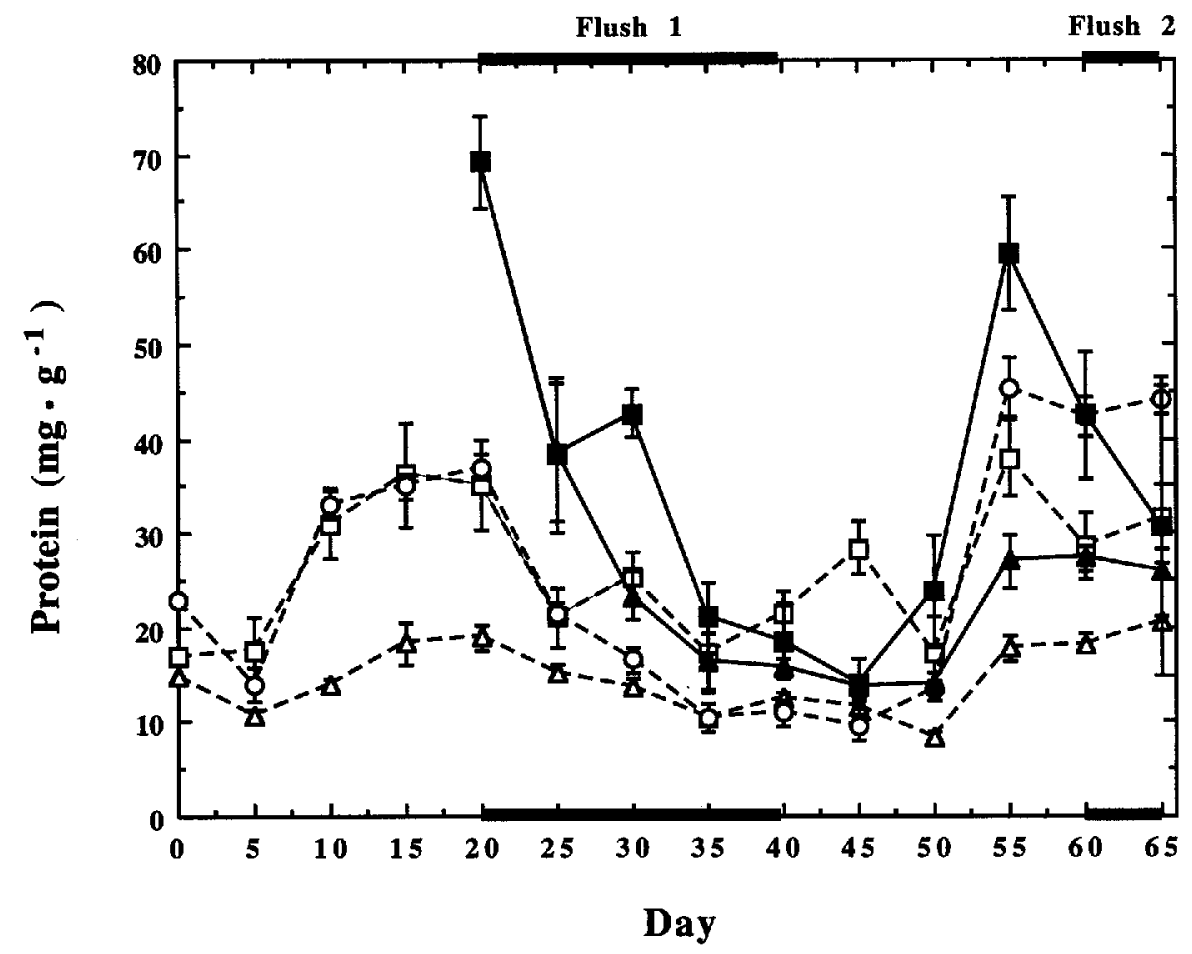




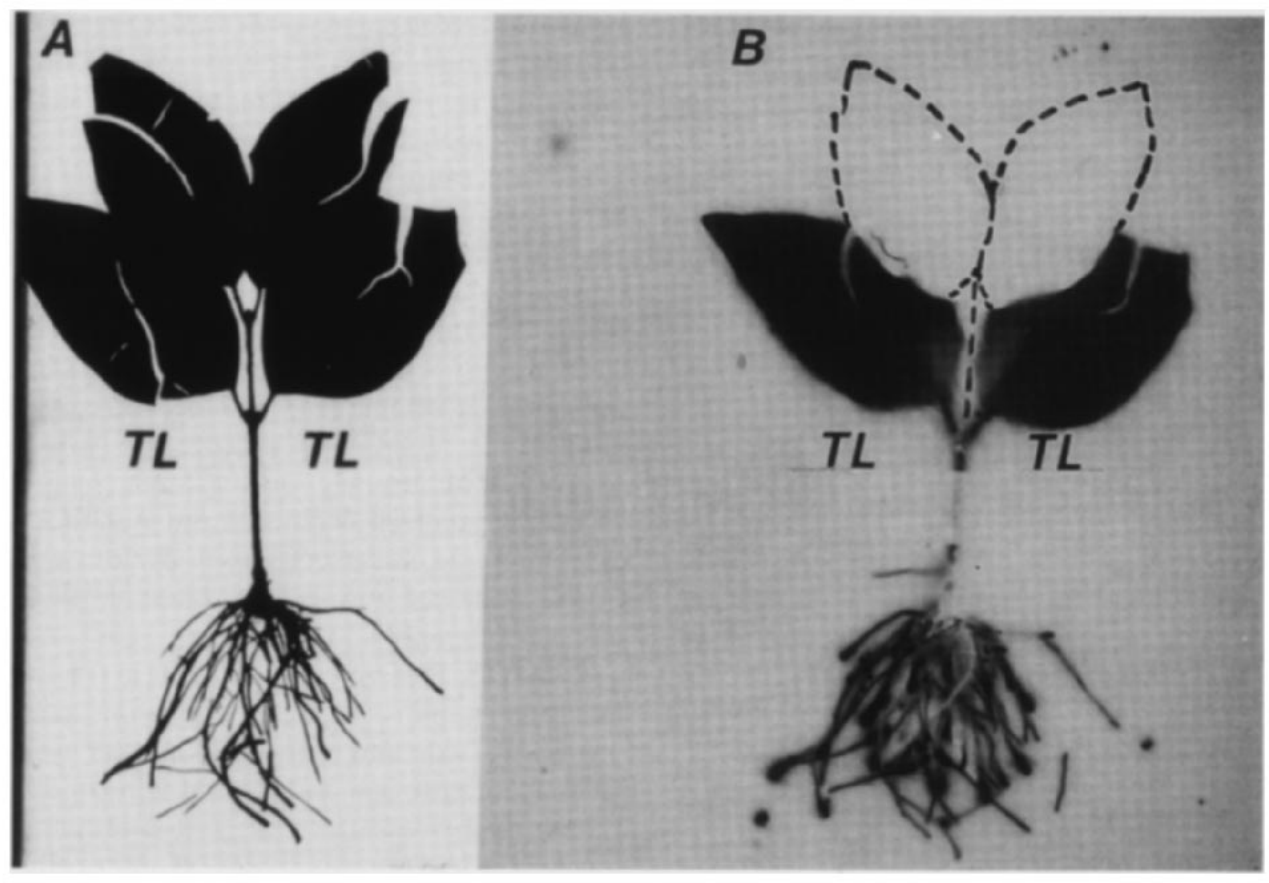

to Harvests 2 and 3 . The ${ }^{15} \mathrm{~N}$ concentration in leaves and stems of the first and second shoot flush of Harvest 2 were not significantly different from Harvest 3 . Nitrogen concentrations, however, increased in all plant tissue at each harvest (Table 2).

\section{Discussion}

Decreased concentrations of soluble sugars in root and stem tissue before shoot elongation and increasing concentration in leaf flush tissue during shoot elongation (Figs. 2 and 3 ) reflect the increased demand for carbohydrates in the shoot. The increase in sugar concentration in the stem and root after day 40 (termination of shoot elongation) concomitant with increasing root growth indicates increased transport of carbohydrate to roots at this time.

The concentration of glucose was higher than all other soluble sugars in all plant tissues throughout the experi-

Fig. 5. Autoradiograph of ligustrum labeled before initiation of the first shoot flush and during the first root growth episode. ${ }^{14} \mathrm{Carbon}$ dioxide was applied to the treated leaf (TL), and after a 24-h chase autoradiography was performed. The two lower mature leaves of the rooted cutting represent the treated leaves. The plant specimen is on the left (A) and the autoradiograph on the right (B) with dashed lines to outline the remainder of the plant specimen. The leaves of the ligustrum in the autoradiographs were slightly cracked, which was caused by the liquid $\mathrm{N}$ and lyophilization process.

${ }^{14}$ Carbon PULSE LABEL. Ligustrum plants were grown through two full shoot flushes and the initiation of third shoot flush for this experiment (data not shown). The leaves of the ligustrum in the autoradiographs were slightly cracked, which was caused by the liquid $\mathrm{N}$ and lyophilization process. An autoradiograph of a ligustrum cutting labeled before initiation of the first period of shoot elongation indicated that all of the fixed ${ }^{14} \mathrm{CO}_{2}$ was translocated to the growing root system (Fig. 5). None of the label was translocated to the two upper leaves or growing tip. Translocation of fixed ${ }^{14} \mathrm{CO}_{2}$ in the plant labeled at the end of shoot elongation of Flush 1 was directed to new shoot growth and to roots (Fig. 6). Fixed ${ }^{14} \mathrm{CO}_{2}$ from the leaves of the first shoot flush labeled at the initiation of the third shoot flush was allocated to the roots (Fig. 7) and not to the initiation of the third shoot flush (Fig. 8 ; Note: Figs. 7 and 8 are the same plant).

${ }^{15}$ Nitrogen PULSE LABEL. The ${ }^{15} \mathrm{~N}$ concentration in mature leaves and stems decreased from Harvest 1 (before initiation of the first shoot flush) and Harvest 2 (at the end of the first shoot flush) to Harvest 3 (at the initiation of the third shoot flush) (Table 1) and decreased in roots from Harvest 1

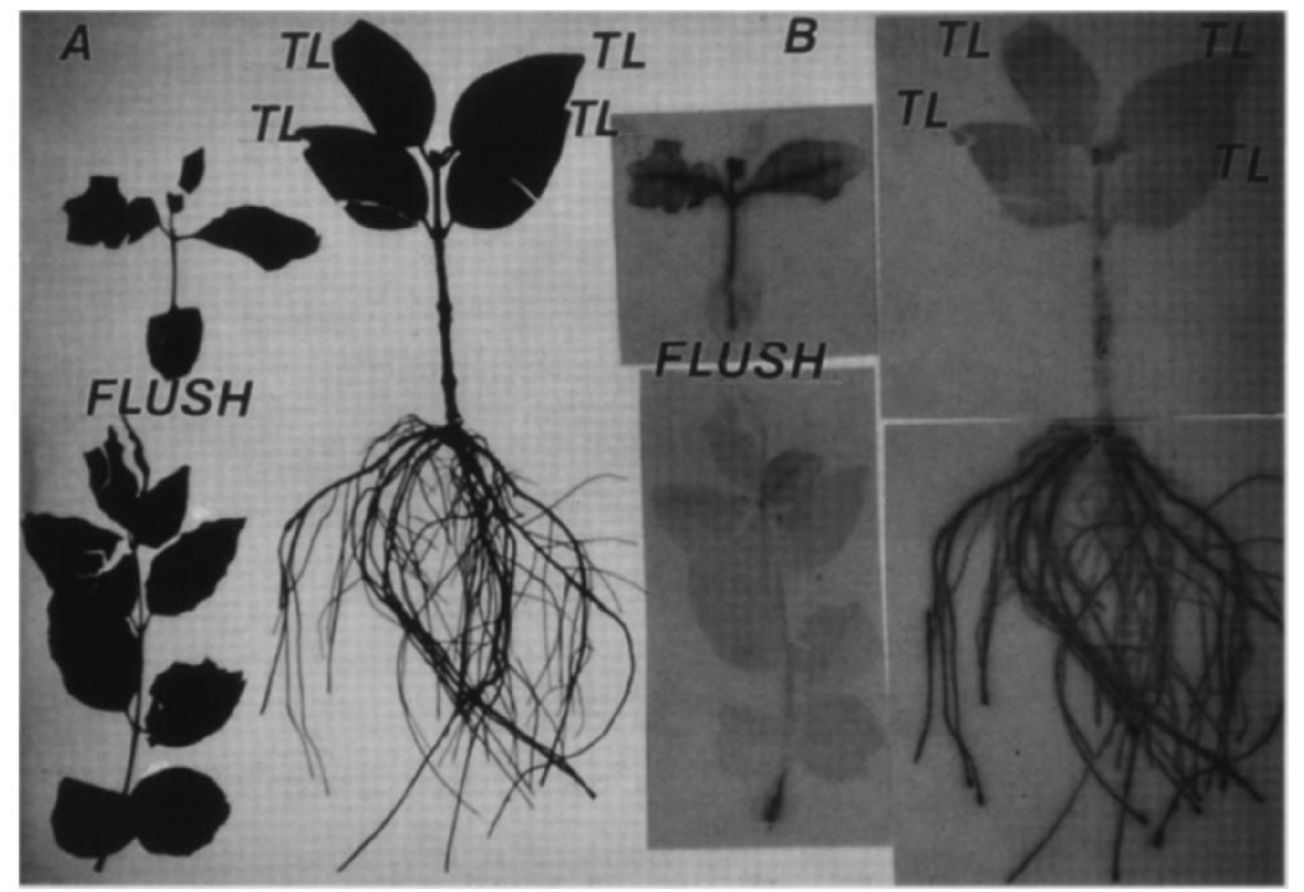




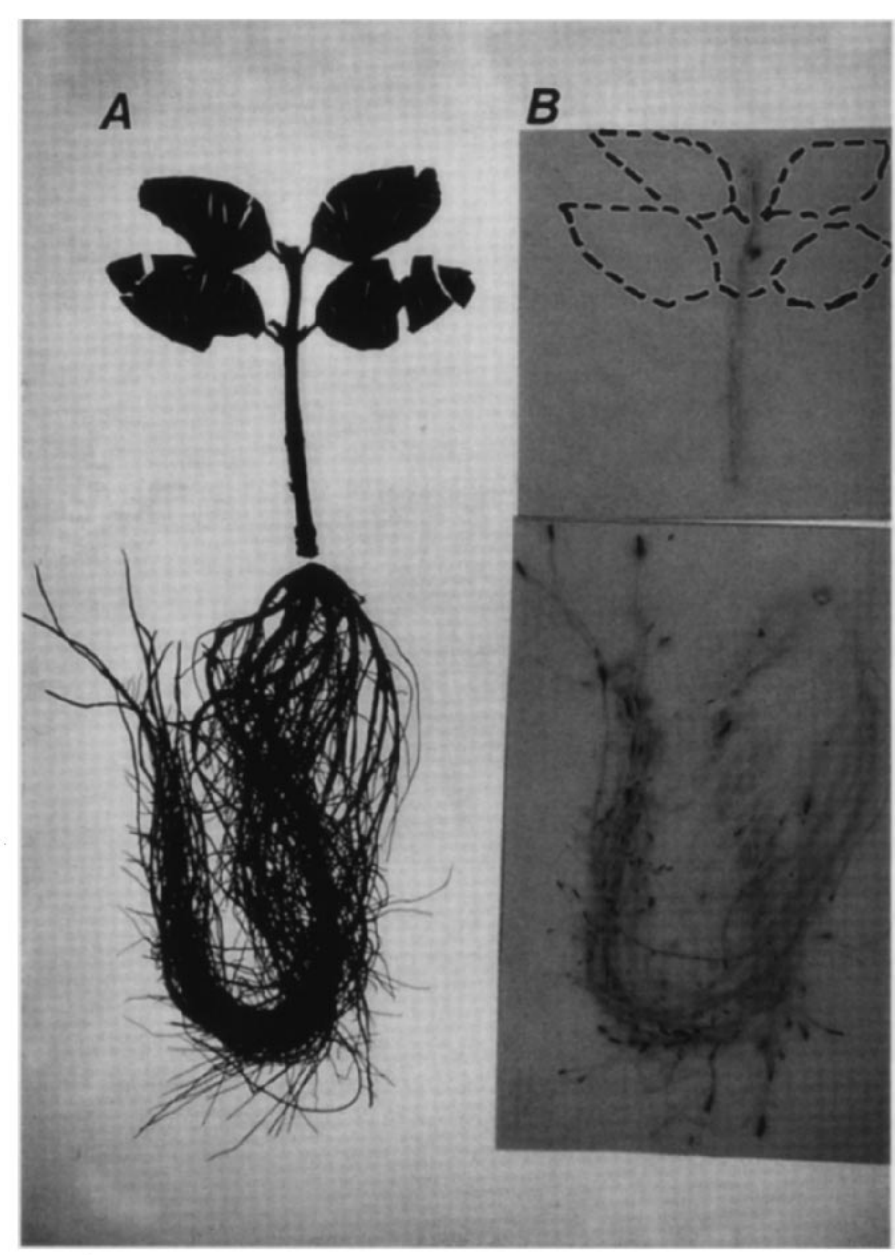

Fig. 7. Autoradiograph of the mature leaves, stem, and root of ligustrum. ${ }^{14} \mathrm{Carbon}$ dioxide was applied to the leaves of the first shoot flush (indicated in Fig. 8) at the initiation of the third shoot flush, and after a 24-h chase autoradiography was performed. The plant specimen is on the left (A) and the autoradiograph on the right (B) with dashed lines to outline the remainder of the plant specimen. The leaves of the ligustrum in the autoradiographs were slightly cracked which was caused by the liquid $\mathrm{N}$ and lyophilization process.

trations (Fig. 2). Sugar alcohols often function as the "common currency" of carbohydrate metabolism in place of neutral sugars like sucrose and starch (Loescher, 1987); thus, mannitol may have served as a supply of carbohydrate for translocation to roots and stems in ligustrum. This was evidenced by the large increase in mannitol concentration in the roots and stems during a shoot growth episode (Fig. 3).

Autoradiographs of ${ }^{14} \mathrm{C}$ labeled plants confirm the observed changes in glucose and mannitol concentrations during episodic shoot and root growth. During a root growth episode, fixed $\mathrm{C}$ was primarily translocated to the root system (Fig. 5). Fixed $\mathrm{C}$ was still being translocated to the shoot flush at the end of shoot elongation and also to the roots just before a root growth episode (Fig. 6). Slcigh et al. (1984) detected ${ }^{14} \mathrm{C}$ in the shoot and root apices of cocoa and suggested that growth at either site may be inhibited if the supply of photosynthate decreased below critical levels and will only be facilitated when the supply is above these levels. We observed that recently assimilated ${ }^{14} \mathrm{C}$ from labeled leaves of the first shoot flush was translocated primarily to the roots and not to the growing tips of the second shoot flush (Figs. 7 and 8). However, the second shoot flush was already established above the first flush; therefore, the leaves of the second shoot flush were probably supporting initiation of a third shoot flush. The leaves of the first shoot flush were then supporting root growth.

Increased protein concentration in the mature leaves and stems during an episode of root growth (Fig. 4) indicated an increased uptake of $\mathrm{N}$ and probably temporary storage for use in the episode of shoot growth. Transformation of soluble protein to structural protein for growth is indicated by the decrease in concentration of soluble protein in all plant tissue during the shoot growth episode. However, during a subsequent root growth episode, the soluble protein concentration increased in all plant tissue.

Similar concentrations of ${ }^{15} \mathrm{~N}$ in leaf and stem Flushes 1 and 2 (Fig. 9B) indicated translocation of stored $\mathrm{N}$ or $\mathrm{N}$ cycling for partial support of shoot growth episodes. Internal cycling of $\mathrm{N}$ in Sitka spruce [Picea sitchensis (Bong.) Carr.] was determined to be a means of enhancing the $\mathrm{N}$ supply to apical growing points during periods of flushing (Millard and Proe, 1992). In Triticum aestivum L. 'Mardler' and Secale cereale L. 'Rheidol' plants, up to $50 \%$ of amino-N can be cycled between the shoot and root (Cooper and Clarkson, 1989). Thus, some ${ }^{15} \mathrm{~N}$ may have been cycled from the shoot back to the roots. Nitrogen assimilated just before the first episode of shoot growth was probably not only used for that



Fig. 8. Autoradiograph of flush one and flush two detached from the ligustrum stem in Fig. 7. ${ }^{14}$ Carbon dioxide was applied to the treated leaf (TL) at the initiation of the third shoot flush, and after a 24-h chase autoradiography was performed. The two mature leaves of the first shoot flush represent the treated leaves. The plant specimen is on the left (A) and the autoradiograph on the right $(\mathbf{B})$ with dashed lines to outline the remainder of the plant specimen. The leaves of the ligustrum in the autoradiographs were slightly cracked which was caused by the liquid $\mathrm{N}$ and lyophilization process. 
Table $1 .{ }^{15}$ Nitrogen concentration (mean $\pm \mathrm{SE}$ ) in mature leaves, stems, roots, flush leaves and flush stems from Harvest 1 (before initiation of the first episode of shoot growth), Harvest 2 (at the end of shoot elongation of the first episode of shoot growth), and Harvest 3 (at the initiation of the third episode of shoot growth).

\begin{tabular}{|c|c|c|c|}
\hline \multirow[b]{2}{*}{ Plant tissue } & \multicolumn{3}{|c|}{${ }^{15} \mathrm{~N}$ concn (mean $\left.\pm \mathrm{SE}\right)\left(\mu \mathrm{mol} \cdot \mathrm{g}^{-1}\right.$ dry mass $)$} \\
\hline & Harvest 1 & Harvest 2 & Harvest 3 \\
\hline Leaves & $89 \pm 6$ & $82 \pm 8$ & $72 \pm 9$ \\
\hline Stems & $22 \pm 3$ & $17 \pm 1$ & $14 \pm 2$ \\
\hline Roots & $143 \pm 40$ & $97 \pm 21$ & $95 \pm 17$ \\
\hline Leaf flush 1 & $\rightarrow$ & $97 \pm 21$ & $113 \pm 22$ \\
\hline Stem flush 1 & -- & $13 \pm 3$ & $12 \pm 4$ \\
\hline Leaf flush 2 & -- & $\cdots$ & $46 \pm 7$ \\
\hline Stem flush 2 & -- & -- & $4 \pm 0.3$ \\
\hline
\end{tabular}

$\overline{\text { No data was reported because the first and second episodes of growth had }}$ not yet occurred.

episode of growth but to support other shoot growth episodes as well. Total $\mathrm{N}$ concentrations in all plant parts increased from Harvest 1 to Harvest 3 (Fig. $10 \mathrm{~A}$ and B). This indicates that the decrease in ${ }^{15} \mathrm{~N}$ in leaves, stems, and roots over Harvests 1 to 3 (Fig. 9A) was probably not a dilution effect but actual retranslocation of $\mathrm{N}$ from mature leaves and root $\mathrm{N}$ storage pools.

The change in carbohydrate and protein concentration $(\mathrm{C}$ and $\mathrm{N}$ pools) in alternate phases signifies the endogenous balance of $\mathrm{C}$ and $\mathrm{N}$ maintained within the plant during alternating episodes of shoot and root growth (Figs. 2-4). We hypothesize that, during a shoot growth episode, the carbohydrate and $\mathrm{N}$ pools in the leaves and stems are depleted. The episode of shoot growth ceases when the carbohydrate and $\mathrm{N}$ pools reach a lower threshold. The carbohydrate pool, however, probably never becomes as depleted as the $\mathrm{N}$ pool. This is due to continued photosynthesis of the mature and flush leaves and the additional photosynthetic activity of leaves on new shoots. Therefore, recently fixed $\mathrm{C}$ and recently stored $\mathrm{C}$ are used for new shoot growth and the amount translocated from new shoot growth to the root for new root growth and $\mathrm{N}$ uptake is minimal. The shoot depends on the root for $\mathrm{N}$, and the $\mathrm{N}$ pools of the leaf and stem are depleted at a much greater rate than the leaf and stem carbohydrate pools.

Furthermore, after cessation of shoot elongation and during leaf maturation of the new shoot flush, carbohydrates are translocated to the root carbohydrate pool to supply structural $C$ and energy for a root growth episode. An episode of root growth then occurs and increased $\mathrm{N}$ uptake and assimilation resupply the root, leaf, and

Table 2. Nitrogen concentration (mean $\pm \mathrm{SE}$ ) in mature leaves, stems, roots, flush leaves and flush stems from Harvest 1 (before initiation of the first episode of shoot growth), Harvest 2 (at the end of shoot elongation of the first episode of shoot growth), and Harvest 3 (at the initiation of the third episode of shoot growth).

\begin{tabular}{|c|c|c|c|}
\hline \multirow[b]{2}{*}{ Plant tissue } & \multicolumn{3}{|c|}{$N$ concn $\left(\right.$ mean \pm SE) $\left(\mu\right.$ mol $\cdot g^{-1}$ dry mass $)$} \\
\hline & Harvest 1 & Harvest 2 & Harvest 3 \\
\hline Leaves & $661 \pm 51$ & $870 \pm 62$ & $990 \pm 173$ \\
\hline Stems & $121 \pm 10$ & $182 \pm 12$ & $381 \pm 74$ \\
\hline Roots & $374 \pm 84$ & $691 \pm 21$ & $2232 \pm 507$ \\
\hline Leaf flush 1 & $\cdots z$ & $1269 \pm 257$ & $3731 \pm 943$ \\
\hline Stem flush 1 & $\cdots$ & $146 \pm 37$ & $420 \pm 165$ \\
\hline Leaf flush 2 & $\cdots$ & -- & $3710 \pm 704$ \\
\hline Stem flush 2 & -- & $\cdots$ & $265 \pm 21$ \\
\hline
\end{tabular}

stem N pools. Since roots are nonphotosynthetic organs, the root carbohydrate pool decreases below a critical level and root growth ceases. Carbohydrates and $\mathrm{N}$ pools of the shoot can then be used for another shoot growth episode. This interdependent cycle of $\mathrm{C}$ and $\mathrm{N}$ throughout the growing season maintains a functional balance between shoot and root growth.

Our results also suggest that $\mathrm{N}$ may be more limiting to the episodes of shoot and root growth than carbohydrate. Carbohydrates are continually supplied by the older leaves and maturing leaves of the shoot flush, and root growth and energy for $\mathrm{N}$ uptake depend on this same supply of carbohydrate. When $\mathrm{N}$ is limiting whole-plant growth, more carbohydrates are translocated to the root for increasing root growth and also stored in the shoot for future episodes of growth. This is suggested by the results of research with birch (Betula nigra), where growth was much less limited by decreased photosynthetic rate per shoot area than decreased $\mathrm{N}$ availability (McDonald et al., 1986a). Thus, growth rates were more likely limited by $\mathrm{N}$ (and other nutrients) availability for growth processes than by photosynthesis (McDonald et al., 1986b).

\section{Literature Cited}

Abo-Hamed, S., H.A. Collin, and K. Hardwick. 1985. Biochemical and physiological aspects of leaf development in Cocoa (Theobroma cacao L.). IX. Water relations and abscisic acid in the control of leaf development. Cafe Cacao 29:155-162.

Awonaike, K.O., K.S. Kumarasinghe, and S.K.A. Danso. 1991. Nitrogen assimilation and distribution in field-grown cowpea at various growth stages. Soil Sci. Soc. Amer. J. 55:81-85.

Bird, K.J. and K. Hardwick. 1982. Carbohydrate balance during flush development in cacao seedlings. 8th Intl. Cocoa Res. Conf. p. 259-264. Bochert, R. 1991. Growth periodicity and dormancy, p. 221-245. In: A.S. Raghavendra (ed.). Physiology of trees. Wiley, New York.

Cooper, H.D. and D.T. Clarkson. 1989. Cycling of amino-nitrogen and other nutrients between shoots and roots in cereals-a possible mechanism integrating shoot and root in the regulation of nutrient uptake. J. Expt. Bot. 40:753-762.

Drew, A.P. and F.T. Ledig. 1980. Episodic growth and relative shoot:root balance in loblolly pine seedlings. Ann. Bot. 45:143-148.

Eastin, E.F. 1978. Total $\mathrm{N}$ determination for plant material containing nitrate. Anal. Biochem. 85:591-594.

Gilliam, C.H. and R.D. Wright. 1978a. Timing of fertilizer application in relation to growth flushes of 'Helleri' holly (Ilex crenata Thunb.). HortScience 13:300-301.

Gilliam, C.H. and R.D. Wright. 1978b. Effects of three nitrogen levels on tissue nitrogen fluctuation during a flush of growth on 'Helleri' holly (Ilex crenata Thunb.). HortScience 13:301-302.

Hershey, D.R. 1981. Mineral nutrition of Euonymus japonica Thunb. $\mathrm{PhD}$ diss., Univ. of California, Davis.

Hershey, D.R. and J.L. Paul. 1983. Ion absorption by a woody plant with episodic growth. HortScience 18:357-359.

Hunt, R. 1982. Plant growth curves: The functional approach to plant growth analysis. Edward Arnold Ltd., London.

Isebrands, J.G. and R.E. Dickson. 1991. Measuring carbohydrate production and distribution: Radiotracer techniques and applications. In: J.P. Lassoie and T.M. Hinckley (eds.). Techniques and approaches in forest tree ecophysiology. CRC Press, Boca Raton, Fla.

Jones, C.G., J.D. Hare, and S.J. Campton. 1989. Measuring plant protein with the Bradford assay. I. Evaluation and standard method. J. Chem. Ecol. 15(3):979-991.

Kuehny, J.S. and M.C. Halbrooks. 1993. Episodic whole plant growth patterns in ligustrum. Physiol. Plant. 89:33-39.

Loescher, W. 1987. Physiology and metabolism of sugar alcohols in higher plants. Physiol. Plant. 70:553-557.

Loescher, W.H., R.H. Tyson, J.D. Everard, R.J. Redgwell, and R.L Beileski. 1992. Mannitol synthesis in higher plants. Evidence for the role 
and characterization of a NADPH-dependent mannose 6-phosphate reductase. Plant Physiol. 98:1396-1402.

McDonald, A.J.S., T. Lohammar, and A. Ericsson. 1986a. Growth response to step-decrease in nutrient availability in small birch (Betula pendula Roth.). Plant Cell Environ. 9:427-432.

McDonald, A.J.S., T. Lohammar, and A. Ericsson. 1986b. Dependence of starch storage on nutrient availability and photon flux density in small birch (Betula pendula Roth.). Plant Cell Environ. 9:433-438.

Mertens, W.C. and R.D. Wright. 1978. Root and shoot growth rate relationships of two cultivars of Japanese holly. J. Amer. Soc. Hort. Sci. 103:722-724.

Miller, W.B. and R.W. Langhans. 1989. Carbohydrate changes of Easter lilies during growth in normal and reduced irradiance environments. $J$. Amer. Soc. Hort. Sci. 114:310-315.

Millard, P. and M.F. Proe. 1992. Storage and internal cycling of nitrogen in relation to seasonal growth of sitka spruce. Tree Physiol. 10:33-43.

Niemiera, A.X. and R.D. Wright. 1982. Influence of medium-nitrogen level on growth periodicity of Ilex crenata Tunb. 'Helleri'. Sci. Hort. 17:81-87.
Priestley, C.A. 1977. The annual turnover of resources in young olive trees. J. Hort. Sci. 52:105-112.

Raper, Jr., C.D., D.L. Osmond, M. Wann, and W.W. Weeks. 1978. Interdependence of root and shoot activities in determining nitrogen uptake of roots. Bot. Gaz. 139:289-234.

Reich, P.B., R.O. Teskey, P.S. Johnson, and T.M. Hinckley. 1980. Periodic root and shoot growth in oak. For. Sci. 26:590-598.

Shim, K.K., K.C. Ko, W.H. Yoo, and Y.H. Ahn. 1983. Mobilization of protein and soluble nitrogen during regrowth of tulip trees (Liriodendron tulipifera L.). J. Kor. Soc. Hort. Sci. 24:228-235.

Sleigh, P.A., H.A. Collin, and K. Hardwick. 1984. Distribution of assimilate during the flush cycle of growth in Theobroma cacao L. Plant Growth Regul. 2:381-391.

Staswick, P.E. 1989. Preferential loss of an abundant storage protein from soybean pods during seed development. Plant. Physiol. 90:1252-1255.

Volk, R.J. and W.A. Jackson. 1979. Preparing nitrogen gas for nitrogen15 analysis. Anal. Chem. 51:463.

Wetzel, S. and J.S. Greenwood. 1989. Proteins as a potential nitrogen storage compound in bark and leaves of several softwoods. Trees 3:149-153. 